\title{
Chemical and Microbiological Properties of Karinyagi (Butter Stored in Rumen) Consumed in Turkey
}

\author{
Gökhan Akarca, Abdullah Çağlar and Oktay Tomar \\ Department of Food Engineering, Faculty of Engineering, University of Afyon Kocatepe, Afyonkarahisar 03100, Turkey
}

\begin{abstract}
In this study, moisture content, peroxide and free fatty acid values and microbial counts of 30 Karinyagi samples taken from different retail markets in Afyonkarahisar province have been investigated. The average moisture content of Karinyagi samples was found to be $17.64 \%$. The average peroxide values of the samples was found $2.33 \mathrm{meq} \mathrm{O}_{2} / \mathrm{kg}$ fat. Free fatty acid values of samples ranged at $2.2-5.2 \mathrm{mg} \mathrm{NaOH} / \mathrm{g}$ fat and the average acidity value was found to be $3.43 \mathrm{mg} \mathrm{NaOH} / \mathrm{g}$ fat. Total aerobic mesophilic bacteria, yeast/mould, coliform group and Micrococcus/Staphylococcus counts of Karinyagi samples were 5.59, 5.54, $2.56,1.24 \log \mathrm{CFU} / \mathrm{g}$ fat, respectively.
\end{abstract}

Key words: Butter, Karinyagi, peroxide value, quality.

\section{Introduction}

Butter is a dairy product with quite large area of use. In Turkish Food Codex, butter is defined as a product produced from milk and/or milk products, from which almost all of the elements of water and fat-free dry matter portions are removed, with a content of milk fat by minimum $80 \%$, up to $90 \%$ by weight, a maximum of $2 \%$ non-fat dry milk solids and maximum of $16 \%$ water [1]. Butter is rich in terms of aroma such that can not be compared with other fats $[2,3]$. Butter is a rich dairy product in terms of minerals, primarily calcium and phosphorus, and it is also a rich source in terms of lecithin and iodine. However, butter consumption has decreased due to its high melting point [4]. It is known that butter has an influence on the cardiovascular disorders and this is referred to the cholesterol content of butter, but there was no solid evidence on this [5].

Karinyagi (butter stored in rumen) is a dairy product obtained especially in Mid-Western Anatolia and Mediterranean region by processing raw milk, cream and yoghurt in different methods, and it is

Corresponding author: Gökhan Akarca, Ph.D., assistant professor, research field: dairy technology. E-mail: gakarca@aku.edu.tr. consumed with pleasure by the local people. Sheep or goat rumen is used in production of Karinyagi [6]. In the first stage of Karinyagi production, sheep or goat rumen (karin) should be prepared. For this purpose, firstly sheep or goat rumen is separated from esophagus entrance and omasum exit, and fats and lymph nodules veins are removed [7]. Rumen is well washed with $1 \% \mathrm{NaOH}$ and rinsed with plenty of water several times. After the completion of washing, rumens are salted and hung to dry approximately in one or two weeks $[6,8]$. Before filling with butter, the rumen is dampened with warm water. Filling butter should be done carefully for no airspace in the upper part of rumen.

Karinyagi is generally produced with cow-milk cream by three different methods [8, 9] (Fig. 1). Karinyagi is kept in the stores of the markets after being filled into karin at $6-10{ }^{\circ} \mathrm{C}$ for about $15 \mathrm{~d}$ [7]. The storage period of Karinyagi should not exceed three months [9]. According to consumer demand, salt (usually $2 \%$ ) is added to Karinyagi and pressed into rumen. Filling proccess should be made carrefully to prevent contamination with microorganisms and lipid oxidation at this stage [6].

The objective of this study was to determine some 


\section{Production stages of Karinyagi}

\section{Method}

Raw milk

$$
\downarrow
$$

Heat treatment

$\left(90-95^{\circ} \mathrm{C}, 15-20 \mathrm{~min}\right)$

Holding (1 d)

ل

Separating cream<smiles>[CH]=C</smiles>

Mixing cream

\ֶ

Separating of buttermilk ป<smiles>[134CH3]</smiles>

Production butter $\sqrt{1}$

Filling rumen (Karin) ป

Sewing of rumen<smiles>[CH]</smiles>

Removing of water<smiles>[CH]=C</smiles>

Storage $\left(4{ }^{\circ} \mathrm{C}\right)$
2. Method

Raw milk

ป

Heat treatment

$\left(95^{\circ} \mathrm{C}, 30 \mathrm{~min}\right)$

Separation

Production

Production cream

لป

Salting cream and holding (2-3 d) \

Washing of concentrated cream لֶ.

Salting

Filling rumen (Karin)

Sewing of rumen

$$
\text { \ }
$$

Removing of water ป

Maturation (one week)

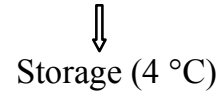

\section{Method}

Raw milk 』

Heat treatment

$\left(95^{\circ} \mathrm{C}, 15 \mathrm{~min}\right)$

Colling $\left(40-45^{\circ} \mathrm{C}\right)$

ل

Inoculation لी Incubation $\left(45^{\circ} \mathrm{C}, 3 \mathrm{~h}\right)$

$\sqrt{ }$

Colling $\left(30^{\circ} \mathrm{C}\right)$

Filling of leather bottle (Tuluk)

Salting

Holding

】

Repetion of process until

filling of leather bottle $\sqrt{ }$

Separation of yoghurt serum

Production of concentrated yoghurt

Obtain drinking yoghurt with added water

Added cold water and mixing l)

Separating of Producing butter

Washing butter

Separating of butter milk $\sqrt{1}$ Salting \

Filling rumen (Karin) Removing of water Storage $\left(4^{\circ} \mathrm{C}\right)$

Fig. 1 Production Methods of Karinyagi [8]. 
chemical and microbiological properties of Karinyagi consumed in Afyonkarahisar province.

\section{Materials and Methods}

The samples used in the research were obtained from 30 different local markets within two months period (Afyonkarahisar province, Mid-Western Anatolia, Turkey). Karinyagi samples were stored in the market at $10 \pm 2{ }^{\circ} \mathrm{C}$. All the samples were immediately brought to laboratory under cold conditions until microbiological and chemical examination. The microbiological evaluation of the samples was performed within the day of sampling. Then, they were held at $-20{ }^{\circ} \mathrm{C}$ until further chemical analyses.

\subsection{Chemical Analysis}

Free fatty acid values and peroxide values of the Karinyagi samples were determined according to Association of Official Analytical Chemists (AOAC, 1985) method. According to the method, samples used for the determination of moisture (\%) were stored at $-20{ }^{\circ} \mathrm{C}[10]$.

\subsection{Microbiological Methods}

$10 \mathrm{~g}$ of each sample was aseptically taken and homogenized for 3 min with sterilized Ringer solution (Merck) at 1:9 (w/v) dilution in a stomacher Lab-Blender 400 (London, UK). Serial decimal dilutions were prepared with sterilized Ringer solution and then plated in duplicate for bacterial counts [11-13]. Each dilution prepared from samples was inoculated in agar using the spreading plate method for total aerobic mesophilic bacteria (TAMB), yeast/mould, coliforms and Micrococcus/Staphylococcus count (Table 1) [14-17].

\subsection{Statistical Analysis}

The results of the chemical and microbiological analyses carried out on Karinyagi samples were compared with TS 1331 butter standard [18] and Turkish Food Codex Communiqué on microbiological criteria butter data [19] for conformability. Statistical package for the social sciences (SPSS, Version 13.0) windows program was used for the statistical analysis [20]. Values of different parameters were expressed as the mean \pm standard error $( \pm \mathrm{SE})$.

\section{Results and Discussion}

\subsection{Free Fatty Acid Values}

The free fatty acid content in milk products indicated hydrolytic deterioration (ranciding) of the triacylglycerols, and this alteration mostly occurs under unsuitable conditions of milk samples. Fats with high water content, like butters, are more susceptible to hydrolysis, and they have a unpleasant odour and taste when they become rancid [21]. On contrary, there is no sginificant $(P>0.05)$ correlation between free fatty acid values and moisture content $(r=0.22$; data not shown). Fatty acid values of Karinyagi samples offered for sale in Afyonkarahisar province were found to be 5.2 (maximum), 2.2 (minimum) and $3.43 \mathrm{mg} \mathrm{NaOH} / \mathrm{g}$ fat (average) (Table 2). Similarly, Tuğcu [22] in his study reported that these values were between $3.11 \mathrm{mg} \mathrm{NaOH} / \mathrm{g}$ fat and $3.17 \mathrm{mg}$ $\mathrm{NaOH} / \mathrm{g}$ fat; Sağdıç et al. [23] reported between 0.66 $\mathrm{mg} \mathrm{NaOH} / \mathrm{g}$ fat and $0.68 \mathrm{mg} \mathrm{NaOH} / \mathrm{g}$ fat; Şenel [24] reported between $0.8 \mathrm{mg} \mathrm{NaOH} / \mathrm{g}$ fat and $2.19 \mathrm{mg}$ $\mathrm{NaOH} / \mathrm{g}$ fat; Gün [8] in his study on some quality characteristics of Karinyagi samples produced in Burdur, reported that the fatty acid values ranged in $0.10-0.34$

Table 1 Analysis performed for microorganism groups and incubation conditions.

\begin{tabular}{llll}
\hline Microorganism & Media & Incubation conditions & Method \\
\hline TAMB & Plate count agar & $30^{\circ} \mathrm{C}, 48-72$ h-aerobic & ISO 4833 [14] \\
Yeast/mould & Potato dextose agar & $22^{\circ} \mathrm{C}, 4-5$ d-aerobic & Pinchardt [15] \\
Coliform & Violet red bile agar & $30^{\circ} \mathrm{C}, 24-48$ h-aerobic & ISO 4832 [16] \\
Micrococcus/Staphylococcus & Baird parker agar & $37^{\circ} \mathrm{C}, 24-48$ h-aerobic & ISO 6888-1 [17] \\
\hline
\end{tabular}


$\mathrm{mg} \mathrm{NaOH} / \mathrm{g}$ fat. Differences in values between the samples are thought to arise from cream used in the production and different post-production conditions of storage and sale and seasonal changes.

\subsection{Peroxide Values of Karinyagi Samples}

Peroxide values in Karinyagi samples were determined as 3.8 (maximum), 0.8 (minimum) and $2.33 \mathrm{meq} \mathrm{O}_{2} / \mathrm{kg}$ fat (average) $(P>0.05)$ (Table 2$)$. Kesler [25] similarly reported that the peroxide values of butter samples ranged in 0.8-2.67 meq $\mathrm{O}_{2} / \mathrm{kg}$ fat; Urkun and Oysun [26] in their study reported that the peroxide values of butter samples were 0-9.17 meq $\mathrm{O}_{2} / \mathrm{kg}$ fat; Efe [27] in their study on butter offered for sale in Ankara market, found that the peroxide values changed between $0.78 \mathrm{meq} \mathrm{O}_{2} / \mathrm{kg}$ fat and $2.45 \mathrm{meq}$ $\mathrm{O}_{2} / \mathrm{kg}$ fat; Şenel [24] reported that the peroxide values varied in 0.22-0.46 meq $\mathrm{O}_{2} / \mathrm{kg}$ fat.

In butter samples stored under normal conditions, peroxide values should be in 0.1-1.0 meq $\mathrm{O}_{2} / \mathrm{kg}$ fat

Table 2 Micriobioligical and chemical contents of Karinyagi samples.

\begin{tabular}{|c|c|c|c|c|c|c|c|}
\hline $\begin{array}{l}\text { Sample } \\
\text { number }\end{array}$ & TAMB & $\begin{array}{l}\text { Yeast and mold } \\
(\log C F U / g)\end{array}$ & $\begin{array}{l}\text { Total coliform } \\
(\log C F U / g)\end{array}$ & $\begin{array}{l}\text { S. aureus } \\
(\log \mathrm{CFU} / \mathrm{g})\end{array}$ & $\begin{array}{l}\text { FFA values } \\
\text { (mg NaOH/g fat) }\end{array}$ & $\begin{array}{l}\begin{array}{l}\text { Peroxide value } \\
\text { (meq } \mathrm{O}_{2} / \mathrm{kg} \text { fat) }\end{array} \\
\end{array}$ & $\begin{array}{l}\text { Moisture value } \\
(\%)\end{array}$ \\
\hline 1 & 4.80 & 3.38 & 2.49 & 1.23 & 4.6 & 3.0 & 19.27 \\
\hline 2 & 4.54 & 3.97 & $<1$ & - & 3.6 & 2.0 & 18.67 \\
\hline 3 & 4.41 & 4.96 & 2.00 & - & 3.0 & 3.2 & 18.99 \\
\hline 4 & 3.90 & 4.86 & 1.83 & $<1$ & 3.4 & 1.0 & 18.87 \\
\hline 5 & 4.23 & 3.28 & $<1$ & - & 3.2 & 1.4 & 19.09 \\
\hline 6 & 5.17 & 4.54 & 2.60 & - & 3.2 & 2.2 & 18.73 \\
\hline 7 & 4.95 & 5.25 & 2.84 & - & 4.4 & 2.8 & 19.54 \\
\hline 8 & 4.89 & 5.14 & 2.61 & - & 2.8 & 2.0 & 15.64 \\
\hline 9 & 4.84 & 4.98 & $<1$ & - & 3.6 & 2.2 & 19.04 \\
\hline 10 & 5.54 & 4.79 & 3.23 & 1.83 & 2.2 & 3.0 & 17.87 \\
\hline 11 & 4.52 & 4.49 & 2.67 & - & 3.4 & 3.4 & 17.83 \\
\hline 12 & 5.69 & 5.44 & $<1$ & 1.07 & 3.2 & 2.8 & 15.83 \\
\hline 13 & 5.64 & 5.43 & 2.61 & 1.97 & 2.8 & 3.4 & 18.89 \\
\hline 14 & 6.30 & 6.30 & 3.07 & - & 4.4 & 3.0 & 14.87 \\
\hline 15 & 5.41 & 5.25 & $<1$ & - & 3.2 & 1.2 & 18.77 \\
\hline 16 & 4.20 & 4.90 & 2.55 & - & 3.0 & 2.2 & 15.87 \\
\hline 17 & 6.32 & 6.30 & 2.74 & 2.38 & 4.4 & 2.2 & 16.93 \\
\hline 18 & 5.20 & 5.14 & $<1$ & 1.64 & 3.2 & 1.6 & 14.33 \\
\hline 19 & 4.68 & 4.91 & 2.57 & - & 4.0 & 2.6 & 18.74 \\
\hline 20 & 4.65 & 4.65 & $<1$ & - & 3.0 & 2.2 & 17.13 \\
\hline 21 & 4.57 & 4.58 & $<1$ & - & 4.6 & 0.8 & 16.18 \\
\hline 22 & 3.20 & 3.20 & 2.50 & 1.20 & 2.8 & 2.0 & 14.94 \\
\hline 23 & 6.30 & 6.30 & 2.67 & - & 3.6 & 2.8 & 18.09 \\
\hline 24 & 3.89 & 3.89 & - & - & 3.2 & 3.8 & 15.52 \\
\hline 25 & 6.32 & 6.32 & 3.23 & - & 2.6 & 2.2 & 16.60 \\
\hline 26 & 3.63 & 3.63 & - & - & 5.2 & 1.6 & 20.64 \\
\hline 27 & 5.40 & 5.39 & 2.72 & 1.28 & 3.6 & 2.0 & 16.84 \\
\hline 28 & 5.25 & 5.07 & 2.86 & - & 3,2 & 1,0 & 17.86 \\
\hline 29 & 4.00 & 4.00 & $<1$ & - & 2.8 & 2.8 & 19.84 \\
\hline 30 & 5.54 & 5.54 & 2.43 & $<1$ & 2.6 & 3.4 & 17.73 \\
\hline Mean & $4.93 \pm 0.83$ & $4.86 \pm 0.87$ & $2.39 \pm 0.35$ & $1.58 \pm 0.46$ & $3.43 \pm 0.71$ & $2.33 \pm 0.79$ & $17.64 \pm 1.65$ \\
\hline
\end{tabular}

TAMB: total aerobic mesophilic bacteria; FFA: free faty acids. 
and should not exceed 0.2 meq $\mathrm{O}_{2} / \mathrm{kg}$ fat in fresh butter samples [28-30]. In TS 1331 butter standard [18], it was notified that the maximum peroxide value should be $5 \mathrm{meq} \mathrm{O}_{2} / \mathrm{kg}$ fat. Accordingly, the peroxide values of Karinyagi samples used in the research were within the specified limits.

\subsection{Moisture (\%) Contents of Karinyagi Samples}

Moisture (\%) contens of Karinyagi samples offered for sale in Afyonkarahisar province were found to be $20.64 \%$ (maximum), $14.33 \%$ (minimum) and $17.64 \%$ (average) (Table 2). As a result of the similar studies, Urkun and Oysun [26] reported that moisture values of their samples ranged between $12.32 \%$ and $15.32 \%$; Efe [27] in his study in Ankara reported that the moisture values of samples ranged between $10.94 \%$ and 17.89\%; Sağdıç et al. [31] reported that the moisture values of their samples ranged between $15.72 \%$ and $15.49 \%$; Tuğcu [22] in her study on the effect of using different cultures on the butter quality, reported the moisture values ranged between $9.52 \%$ and $10.74 \%$; Gün [8] reported that the moisture of Karinyagi samples ranged between $12.0 \%$ and $17.44 \%$.

When the autors' results are compared with similar results, it was found that the moisture (\%) values of samples are higher than all the samples from similar studies. This is considered to be due to the production conditions of the butter and inadequate post-production quality control analyses.

\subsection{Microbiological Analysis}

\subsubsection{Total Aerobic Mesophilic Bacteria Counts}

TAMB counts in Karinyagi samples were found 6.32 (maximum), 3.20 (minimum) and $5.59 \mathrm{log}$ CFU/g (average) $(P<0.05)$ (Table 2$)$. Similar to the study, Patır et al. [32] in their study on determination of quality of breakfast butters offered to consumption in Elazı $\breve{g}$ province, found the total microorganism count as $6.95 \log$ CFU/g. Gün [8] in his study on some quality characteristics of Karinyagi products produced in Burdur, found the total bacteria count of samples between $2.14 \log \mathrm{CFU} / \mathrm{g}$ and $7.00 \log \mathrm{CFU} / \mathrm{g}$. The differences of bacteria counts between samples were due to poor hygiene and sanitation practices in production, and storage and sales conditions of Karinyagi products.

\subsubsection{Coliform Group Bacteria Counts}

In the study, the total coliform group bacteria count of the samples was found $2.56 \mathrm{log} \mathrm{CFU} / \mathrm{g}$ on average $(P<0.05)$ (Table 2). In similar studies, Esis [33] reported that the coliform group bacteria counts varied in 0-5.09 $\log \mathrm{CFU} / \mathrm{g}$. Gün [8] found the coliform group bacteria counts in Karinyagi samples produced in Burdur between $0 \log \mathrm{CFU} / \mathrm{g}$ and $2.82 \mathrm{Log} \mathrm{CFU} / \mathrm{g}$. In another study, Doğan et al. [34] found that coliform group bacteria counts in butter samples ranged in 0-3 $\log \mathrm{CFU} / \mathrm{g}$ and $57.5 \%$ these bacteria of the samples have proliferated. In Ref. [8], 53.8\% total coliform bacteria counts of 91 butter samples were found higher than the levels notified in the microbiological criteria of Turkish Codex [1]. The differences between the samples are considered to result from the microbiological quality of the cream, cleaning and storage conditions of the leather bottle in which the butter is placed and the inadequate hygiene and sanitation practices during production, storage and sale.

\subsubsection{Yeast and Mould Counts}

In Karinyagi samples, yeast and mould counts were 6.0 (maximum), 3.28 (minimum) and $5.54 \mathrm{log} \mathrm{CFU} / \mathrm{g}$ (average) $(P<0.05)$ (Table 2). Similar to the results, Hayaloğlu and Konar [35] in their study on microbiological characteristics of 25 butter samples produced from yoghurt and cream in Malatya region, reported the yeast and mould count $6.69 \mathrm{log} \mathrm{CFU} / \mathrm{g}$ and Gün [8] reported that the yeast and mould count of Karinyagi samples produced in Burdur varied in 0-3.94 log CFU/g. The differences between results are thought to result especially from the inadequate importance given to hygiene and sanitation guidelines in post-production. 


\subsubsection{Micrococcus/Staphylococcus (Coagulase} Positive Staphylococci) Counts

Micrococcus/Staphylococcus (coagulase positive Staphylococci) counts of Karinyagi samples were found $1.24 \log \mathrm{CFU} / \mathrm{g}$ on average $(P>0.05)$ (Table 2$)$. In 20 samples used in the study, no Micrococcus/Staphylococcus (coagulase positive Staphylococci) proliferations were observed. This primarily indicates that the hygiene and sanitation guidelines were adequately followed in production and post-production phases and especially there were no human originated contaminations. Related to the samples in which the Micrococcus/Staphylococcus activity was detected, it is concluded that the personnel hygiene guidelines were not followed, primarily in production and storage stages.

\section{Conclusions}

In this study, some chemical and microbiological properties of 30 Karinyagi samples offered to sale in different regions of Afyonkarahisar province were determined. It was found that $68.5 \%$ of these samples in terms of chemical characteristics and $90 \%$ of these samples in terms of microbiological characteristics were not in accordance with the limit values specified in TS 1331 butter standard and Turkish Food Codex Communiqué of microbiological criteria in the butter section. High water rates in samples, especially in those collected from retail markets, show clearly that the samples sold in these places are not adequately controlled and this is an abuse of the manufacturer.

It is significantly observed that the higher counts of coliform bacteria and yeast and mould found in Karinyagi samples are due to sales of these products unpackaged and without paying attention to the guidelines of hygiene and sanitation; this constitutes a risk to public health. The authors obviously emphasize the necessity of increasing the controls in order to improve the conditions regarding production and sales of Karinyagi, which is consumed with pleasure by local people. It is essential to utilize more technology in Karinyagi production to follow the hygiene and sanitation guidelines, to intensify the controls in production and sales places by relevant agencies and organizations and to speed up work on the dissemination for this subject throughout the country.

As a result, with the increasing quality of Karinyagi, which is a local product identified with a unique taste and aroma, the narrowed consumption of this product in a certain area will be spreaded throughout the country and the production will be standardized.

\section{References}

[1] Turkish Food Codex. 2005. "Notification of Butter and Other Spread Able Milk Fat Based Product." Turkish Food Codex No. 2005/192005. Accessed February 13, 2015. http://mevzuat.basbakanlik.gov.tr.

[2] German, J. B., and Dillard, C. J. 1998. "Fractionated Milk Fat: Composition Structure and Functional Properties." Food Technology 52 (2): 33-8.

[3] Tekinşen, C. 2000. Dairy Products Technology. Konya Turkey: Selçuk University Press, 122.

[4] Demici, M. 2011. Nutrition. İstanbul, Turkey: Onur Graphic Publisher, 370-5.

[5] Huts, P. J., and Park, K. M. 2012. "Influence of Dairy Product and Milk Fat Consumption on Cardiovascular Disease Risk." Adv. Nutr. 3 (3): 266-85.

[6] Gün, İ., and Şimşek, B. 2011. "The Fatty Acid Composition of Butter Stored in Sheep's or Goat Stomach (Karinyagi)." Food and Nutrition Science 2 (5): 402-6.

[7] Gökçe, R., Aslanalp, Y., and Herken, E. N. 2010. "Microbiological Quality of Karın Butter-A Traditionally Manufactured Butter from Turkey." Grasas y Aceties 61 (2): 121-5.

[8] Gün, İ. 2003. "Karinyagi of Some Characteristics of Quality and Production Technology Produced in Burdur." Journal of Natural and Applied Science 7 (3): 55-9.

[9] Gökçe, R., Akdoğan, A., Divriklib, U., and Elçi, L. 2014. "Simultaneous Determination of Diacetyl and Acetoin in Traditional Turkish Butter Stored in Sheep's Rumen (Karinyagi)." Grasas y Aceties 65 (1): 1-6.

[10] Association of Official Analytical Chemists (AOAC) 1995. "Food Composition, Additives, Natural Contaminants." In Official Methods of Analysis of the Association of Official Analytical Chemists, 16th ed.. Arlington, Virginia, USA: AOAC.

[11] Sekin, Y., and Karagözlü, N. 2004. Food Microbiology Basic Principles and Applications for Food Industry, 4th ed., translated by Pichhardt, K. İstanbul, Turkey: 
Literatür Press, 358.

[12] Turkish Standart Organization. 2001. "Microbiology of Food and Animal Feed General Rukes for Starts of Tests Speciments of the Suspencions and Preparation of Decimal Dilutions." TS 6235 EN ISO 6887-1, Turkey. Accessed $\quad$ February 2015. https://intweb.tse.org.tr/standard/standard/Standard.aspx.

[13] Halkman, K. 2005. Food Microbiology Applications. Ankara, Turkey: Başak Printing, 358.

[14] International Standart Organisation (ISO). 2003. "Horizontal Method for the Enumaration of Microorganism: Colony Count Technique at $30{ }^{\circ} \mathrm{C}$." ISO4833. Accessed February 11, 2015. http://www.iso.org/iso/catalogue_detail.htm?csnumber $=5$ 3728.

[15] Pichhardt, K. 1993. Lebensmittelmikrobiologie. Berlin, German: Springer Verlag, 117-93.

[16] International Standart Organisation (ISO). 1991. "General Guidance for the Enumaration of Coliforms, Colony Count Technique." ISO 4832. Accessed February 11, 2015. http://www.iso.org/iso/catalogue_detail.htm?csnum ber $=38282$.

[17] International Standart Organisation (ISO). 1999. "Microbiology of Food and Animal Feeding Stuffs-Horizontal Method for the Enumeration of Coagulase-Positive Staphylococci (Staphylococcus aureus) and Other Species: Part 1, Technique Using Baird-Parker Agar Medium International Organisation for Standardization.” EN ISO 6888-1, Geneva. Accessed January 23 , 2015. https://www.iso.org/obp/ui/\#iso:std:iso:6888:-1:ed-1:v1:en.

[18] Turkish Stardart Organization. 1999. TS-1331 Standart of Butter. Ankara, Turkey: TSE Publications.

[19] Turkish Food Codex. 2009. Turkish Food Codex Communiqué of the Microbiological Criteria. 2009/68, Ankara,Turkey.

[20] Statistical Product and Service Solutions (SPSS). 2004. SPSS 13.0.0 for Windows. Chicago IL: SPSS Inc..

[21] Koczori, P., Gruczynska, E., and Kowalski, B. 2008. "Changes in the Acid Value of Butter during Storage at Different Temperature as Assassed by Standart Methods or by FT-IR Spectroscopy." American Journal of Food Technology 3 (3): 154-63.

[22] Tuğcu, M. 2005. "Effects of Using Different Cultures on Quality of Butter." M.Sc. thesis, Graduate School of Natural and Applied Science, Ege University, İzmir, Turkey.

[23] Sagdıç, O., Dönmez, M., and Demirci, M. 2004. "Comparison of Characteristics and Fatt Acid Profiles of
Traditional Turkish Yayik Butter Produced from Goats, Ewes or Cows Milk." Food Control 15 (6): 485-90.

[24] Şenel, E. 2006. "The Effect of Some Production Parameters on Yayık Butter Produced from Butter.” Ph.D. thesis, Graduate School of Natural and Applied Science, Ankara University, Ankara, Turkey.

[25] Kesler, Y. 2008. "The Production of Functional Butter with Addition of Food Fiber and Probiotic Bacteria." M.Sc. thesis, Graduate School of Natural and Applied Science, Erciyes University, Kayseri, Turkey.

[26] Urkun, T., and Oysun, G. 1998. "Reduced Cholesterol Butter and Determination of Some Parameters." In Proceeding of Food Engineering Congress and Exhibition, 65-73.

[27] Efe, M. 1998. "Determination of Suitability Breakfast Butter of Set of Vacum Packed Food Subtance Regulation TSE and Ministry of Defence of Consumed in Ankara Markets." M.Sc. thesis, Graduate School of Natural and Applied Science, Ankara University, Ankara, Turkey.

[28] Kurt, A., Çağlar, A., and Çakmakçı, S. 2012. Guide of Dairy Products Examination and Analysis Methods. Erzurum, Turkey: Agriculture Faculty of Atatürk Univesity, 238.

[29] Oysun, G. 1996. Methods of Analysis of Milk and Dairy Products. İzmir, Turkey: Ege Univesity Agriculture Faculty Press, 122.

[30] Metin, M., and Öztürk, G. F. 2010. Methods of Analysis of Milk and Dairy Products. İzmir, Turkey: Ege Vocational School Press, 439.

[31] Sağdıç, O., Arıc1, M., and Şimşek, O. 2002. "Selection of Starters for a Traditional Turkish Yay1k Butter Made from Yoghurt." Food Microbiology 19 (4): 303-12.

[32] Patır, B., Güven, A., and Saltan, S. 1995. "Studies on Quality of Butter Consumed in Elazığ.” Eurasian Journal of Veterinary Sciences 11 (1): 77-81.

[33] Esis, I. 1997. "A Research on Physical Chemical and Microbiological Properties of Butter Offered for Sale in Ağrı Markets." M.Sc. thesis, Graduate School of Natural and Applied Science, Trakya University, Tekirdağ, Turkey.

[34] Doğan, H. B., Çakır, Đ., Keven, F., Cosansu, S., Kıral, N., Dağer, T., Gürsu, G., and Halkman, K. 2001. "Coliform, Fecal Coliform and Escherichia coli Presence in Various Foods." Journal of Association of Food Technology 26 (2): 83-90.

[35] Hayaloğlu, A. A., and Konar, A. 2001. “A Comparative Study on Microbiological Quality of Butter Produced from Yogurt and Cream in Malatya Region." Journal of Association of Food Technology 26 (6): 429-35. 